\title{
Follow-up of cyclosporin A treatment in Type 1 (insulin-dependent) diabetes mellitus: lack of long-term effects*
}

\author{
S.Martin ${ }^{1}$, G.Schernthaner ${ }^{2}$, J.Nerup ${ }^{3}$, F.A.Gries ${ }^{1}$, V.A.Koivisto ${ }^{4}$, J.Dupré ${ }^{5}$, E.Standl ${ }^{6}$, P.Hamet ${ }^{7}$, R.McArthur ${ }^{8}$, \\ M.H.Tan ${ }^{9}$, K. Dawson ${ }^{10}$, A. E. Mehta ${ }^{11}$, S. Van Vliet ${ }^{12}$, B.von Graffenried ${ }^{13}$, C. Stiller ${ }^{5}$ and H. Kolb $^{1}$
}

${ }^{1}$ Diabetes Research Institute, University of Düsseldorf, Düsseldorf, FRG, ${ }^{2}$ Krankenanstalt Rudolfstiftung, Vienna, Austria.

${ }^{3}$ Steno Memorial Hospital, Gentofte, Denmark, ${ }^{4}$ Second Department of Medicine, Helsinki University, Helsinki, Finland,

5 University Hospital, London, Ontario, Canada, ${ }^{6}$ Städtisches Krankenhaus München-Schwabing, Munich, FRG,

${ }^{7}$ Clinical Research Institute, Montreal, Quebec, ${ }^{8}$ Alberta Children's Hospital, University of Calgary, Calgary, Alberta,

${ }^{9}$ Camp Hill Medical Centre, Halifax, Nova Scotia, ${ }^{10}$ University Hospital, Vancouver, British Columbia,

${ }^{11}$ Health Science Centre, Winnipeg, Manitoba, ${ }^{12}$ University of Saskatchewan, Saskatoon, Saskatchewan, Canada, and

13 Sandoz, Basal, Switzerland

Summary. In the Canadian/European randomized controlled study on cyclosporin A (CsA) in recent onset Type 1 (insulin-dependent) diabetes, treatment with the immunosuppressive drug had increased and maintained Beta-cell function and clinical remission during the first 12 months. Following discontinuation of the study drug and doubleblinding after a mean of 13.8 months former CsA patients doubled the daily insulin dose within 6 months reaching the level of former placebo patients. The difference in Beta-cell function between the two groups was also lost. Metabolic control $\left(\mathrm{HbA}_{\mathrm{ic}}\right)$ was transiently worse in the former CsA group. Adverse effects of cyclosporin A on systolic blood pressure, haemoglobin levels, serum potassium and creatinine levels also remitted during that time. We conclude that treatment with cyclosporin A for a mean of 13.8 months had no long-lasting effect on the course of Type 1 diabetes persisting beyond drug discontinuation.

Key words: Cyclosporin A, Type 1 (insulin-dependent) diabetes mellitus, immunotherapy, C-peptide, islet function, remission of Type 1 diabetes.
When patients with recent onset Type 1 (insulin-dependent) diabetes mellitus were treated with the immunosuppressive drug cyclosporin $\mathrm{A}$ an increase in the rate and lengths of remissions was observed [1-3] with concomitant improvement and preservation of Beta-cell function [3].

In these as well as in other studies the administration of cyclosporin A was discontinued within two years because of loss of clinical remission, because of risk of sideeffects or at the patients' request [4-7]. However, little is known about the further course of Type 1 diabetes in these patients. Animal studies [8-10] and data from a small numbers of patients [11] have indicated that a limited period of CsA administration may have a longlasting beneficial effect in Type 1 diabetes. Follow-up data of a large cohort from the Canadian/European randomized controlled trial were analysed for long-term effects on the course of Type 1 diabetes after discontinuation of CsA therapy.

\footnotetext{
* Prepared by the authors on behalf of The Canadian/European Randomized Control Trial Group (Please see acknowledgements for complete listing).
}

\section{Subjects and methods}

The patients and methods used for this analysis have been described elsewhere in more detail [3]. In brief, 188 recent onset Type 1 diabetic patients (age 9-35 years, duration of classic symptoms before onset < 14 weeks) were randomized in two groups. The initial cyclosporin A dose was $10 \mathrm{mg} / \mathrm{kg}$ divided in $12 \mathrm{~h}$ intervals, subsequently the dose was modified to maintain $12 \mathrm{~h}$ trough concentrations in serum of $100-200 \mathrm{ng} / \mathrm{ml}$ or in whole blood of $400-800 \mathrm{ng} / \mathrm{ml}$ (determined by radioimmunoassay with the polyclonal antibody provided by Sandoz, Basel, Switzerland). An increase of serum creatinine to $>150 \%$ of baseline values called for cyclosporin $\mathrm{A}$ dose reduction.

Insulin was administered with the objective of mean capillary blood glucose levels less than $7.8 \mathrm{mmol} / \mathrm{l}$ with no single blood glucose value more than $9.0 \mathrm{mmol} / \mathrm{l}$ before meals and before bedtime. Endogenous secretion of insulin was tested before and $6 \mathrm{~min}$ after $1 \mathrm{mg}$ glucagon i. v. in the overnight-fasted state without prior administration of insulin and with blood glucose levels below $7.8 \mathrm{mmol} / 1$.

\section{Twin analysis}

To evaluate the follow-up after cyclosporin discontinuation patients still on drug treatment or with an incomplete record had to be excluded. Of the cyclosporin A group 63 patients with complete record 
A

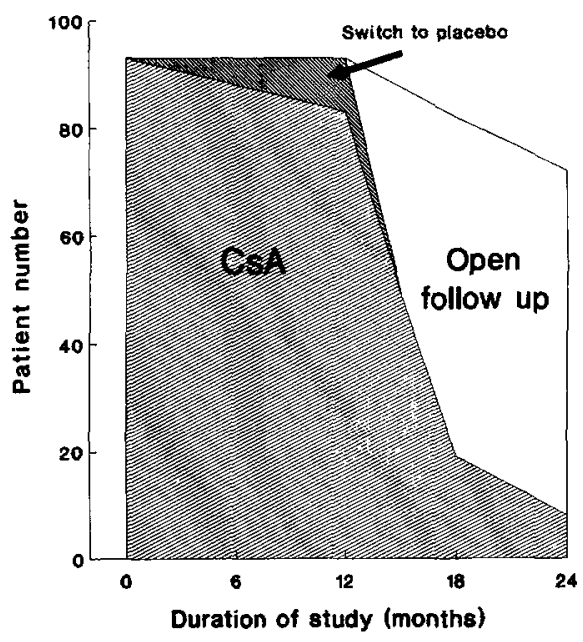

B

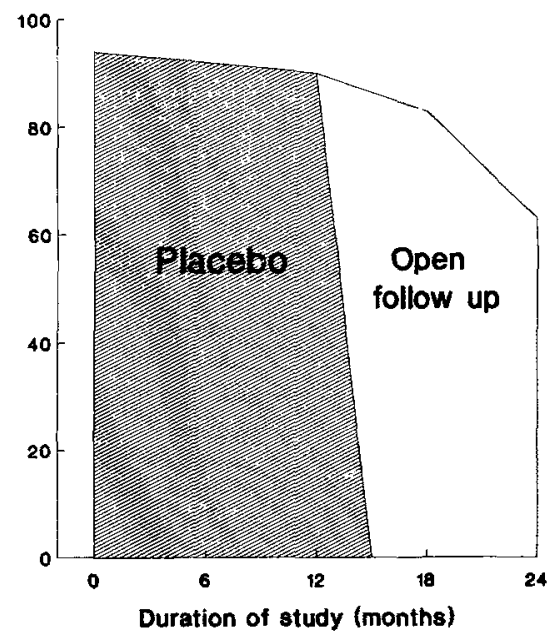

Fig.1A,B. Number of patients before and after discontinuation of double-blinding. During the double-blind phase of the study some patients were switched to placebo in order to minimize risk from toxicity if there was no prospect of benefit (basal C-peptide $<0.1 \mathrm{nmol} / 1$ on two consecutive months) after drug discontinuation were available and for each a matching statistical twin was searched in the placebo group. The following criteria were defined for matching: same sex, age difference less than 4 years, initial glucagon stimulated $C$-peptide difference less than $0.15 \mathrm{nmol} / \mathrm{h}$ and difference in duration of diabetic symptoms before therapy less than 3 weeks. Following these criteria 46 statistical twin pairs could be formed. Between the former CsA and placebo twins only corresponding data were compared, i. e. with identical duration in the study.

\section{Statistical analysis}

Statistical analyses were performed by using Student's $t$-test (twotailed), Wilcoxon test and Fisher's-test with the level of significance at $p<0.05$.

\section{Results}

The follow-up of all patients in the Canadian/European cyclosporin A trial is shown in Figure 1. Double blinding and placebo treatment were discontinued $12-15$ months after entry when patients and physicians were informed about the nature of the individual study drug. Cyclosporin A administration was continued at the patient's request as long as target control of glycaemia was maintained (blood glucose levels $\leq 7.8 \mathrm{mmol} / \mathrm{l}$ before meals) and the daily insulin dose was $\leq 0.15 \mathrm{IU} / \mathrm{kg}$. All patients were asked to participate in the follow-up analyses. As shown in Figure 1 this was the case for the majority of patients remaining in the study.

In Table 1 a summary of all available data, including patients who did not discontinue CsA is given. At 24 months after entry to the study patients of the former CsA group showed similar insulin requirements, glycosylated $\mathrm{HbA}_{1 \mathrm{c}}$ levels, basal and stimulated C-peptide concentrations as was found for former placebo patients.

As described above, 46 statistical twin pairs with complete records were formed to analyse the long-term effects of CsA after drug discontinuation. The statistical twins did not differ in entry characteristics from the total group of randomized patients and thus can be regarded as representative (Table 2).
Cyclosporin A administration was discontinued at a mean of $13.8 \pm 7.4$ months (SD). Within 6 months the mean insulin dose more than doubled $(+111 \%)$ compared to a modest increase in the former placebo patients $(+21 \%)$ (Fig. 2a). Similarly the significantly higher mean basal and stimulated C-peptide values of the CsA patients fell within half a year to the level of the former placebo patients. Glycaemic control was transiently worse in the former CsA patients (Fig. 2a).

Of a large number of biochemical and other parameters studied during the double blind phase of the study [3] four (serum creatinine, potassium, haemoglobin, systolic blood pressure) had shown a significant adverse effect of CsA. During follow-up after drug discontinuation all of the parameters remitted to the range of the former placebo group within 6 months (Fig. 2b).

Because of the individual variation in serum creatinine values a single patient analysis was performed. As shown in Figure 3 each patient approached his pre-CsA level of serum creatinine after discontinuation of CsA.

\section{Discussion}

After termination of double-blinding and discontinuation of the study drug, compliance of patients allowed a follow-up in the large majority of study participants. Compared to metabolic data shortly before termination of CsA therapy there was a striking increase in insulin dose, loss of Beta-cell function and worsening of glycaemic control, i.e. basic parameters of the disease rapidly approached the level of the former placebo group. The twin analysis did not consider the small fraction of patients who had not discontinued CsA during the followup. However, when these were included and compared to the total of former placebo patients, again no difference in metabolic control between the two groups existed (Table 1).

We therefore conclude that the administration of CsA in recent onset Type 1 diabetes for a mean of 13.8 months did not have a long-lasting impact on the course of diabetes persisting beyond drug discontinuation. This conclusion may be at variance with follow-up data of for- 
Table 1. Descriptive data of all patients studied

\begin{tabular}{|c|c|c|c|c|}
\hline & \multirow[t]{2}{*}{ Before start of therapy } & \multicolumn{3}{|c|}{ After start of therapy } \\
\hline & & 12 months & 18 months & 24 months \\
\hline $\begin{array}{l}\text { Insulin dose }\left(\mathrm{IU} \cdot \mathrm{kg}^{-1} \cdot \mathrm{day}^{-1}\right) \\
\text { Cyclosporin A } \\
\text { Placebo }\end{array}$ & $\begin{array}{l}0.53 \pm 0.27 \\
0.47 \pm 0.21\end{array}$ & $\begin{array}{l}0.30 \pm 0.27 \\
0.35 \pm 0.24\end{array}$ & $\begin{array}{l}0.41 \pm 0.33 \\
0.43 \pm 0.25\end{array}$ & $\begin{array}{l}0.50 \pm 0.34 \\
0.48 \pm 0.24\end{array}$ \\
\hline $\begin{array}{l}\text { Basal C-peptide }(\mathrm{nmol} / \mathrm{l}) \\
\text { Cyclosporin A } \\
\text { Placebo }\end{array}$ & $\begin{array}{l}0.22 \pm 0.09 \\
0.23 \pm 0.11\end{array}$ & $\begin{array}{r}0.26^{\mathrm{b}} \pm 0.12 \\
0.21 \pm 0.12\end{array}$ & $\begin{array}{r}0.23^{\mathrm{a}} \pm 0.13 \\
0.19 \pm 0.12\end{array}$ & $\begin{array}{l}0.18 \pm 0.22 \\
0.18 \pm 0.24\end{array}$ \\
\hline $\begin{array}{l}\mathrm{HbA}_{1 \mathrm{c}}(\%) \\
\text { Cyclosporin A } \\
\text { Placebo }\end{array}$ & $\begin{array}{l}10.5 \pm 2.2 \\
10.2 \pm 2.3\end{array}$ & $\begin{array}{l}7.4 \pm 2.2 \\
7.3 \pm 2.0\end{array}$ & $\begin{array}{l}8.3 \pm 2.1 \\
7.8 \pm 2.0\end{array}$ & $\begin{array}{l}8.6 \pm 2.4 \\
8.0 \pm 2.3\end{array}$ \\
\hline $\begin{array}{l}\text { Systolic blood pressure }(\mathrm{mm} \mathrm{Hg}) \\
\text { Cyclosporin A } \\
\text { Placebo }\end{array}$ & $\begin{array}{l}117 \pm 13 \\
116 \pm 11\end{array}$ & $\begin{array}{l}119 \pm 15 \\
117 \pm 14\end{array}$ & $\begin{array}{l}119 \pm 14 \\
115 \pm 15\end{array}$ & $\begin{array}{l}122 \pm 17 \\
117 \pm 14\end{array}$ \\
\hline $\begin{array}{l}\text { Potassium }(\mathrm{mmol} / 1) \\
\text { Cyclosporin A } \\
\text { Placebo }\end{array}$ & $\begin{array}{l}4.3 \pm 0.4 \\
4.3 \pm 0.4\end{array}$ & $\begin{array}{r}4.7^{c} \pm 0.5 \\
4.3 \pm 0.3\end{array}$ & $\begin{array}{l}4.3 \pm 0.4 \\
4.2 \pm 0.3\end{array}$ & $\begin{array}{l}4.3 \pm 0.4 \\
4.3 \pm 0.3\end{array}$ \\
\hline
\end{tabular}

The numbers of patients available at the different dates are given in Figure 1. All the patients are documented, including those who did not discontinue CsA by 24 months. Given are mean values \pm SD. ${ }^{a} p<0.05 ;{ }^{\mathrm{b}} p<0.01 ;{ }^{c} p<0.001$ between CsA and placebo groups

Table 2. Characteristics at entry of all patients and of statistical twin pairs

\begin{tabular}{|c|c|c|c|c|}
\hline & \multicolumn{2}{|l|}{ All patients } & \multicolumn{2}{|c|}{ Statistical twins } \\
\hline & $\begin{array}{l}\text { Cyclo- } \\
\text { sporin A }\end{array}$ & Placebo & $\begin{array}{l}\text { Cyclo- } \\
\text { sporin A }\end{array}$ & Placebo \\
\hline Number $(n)$ & 93 & 95 & 46 & 46 \\
\hline Sex & & & & \\
\hline Male (n) & 74 & 72 & 36 & 36 \\
\hline Female $(n)$ & 19 & 23 & 10 & 10 \\
\hline $\begin{array}{l}\text { Age at entry } \\
(\text { mean } \pm \mathrm{SD})\end{array}$ & $21.5 \pm 6.4$ & $22.4 \pm 5.0$ & $21.0 \pm 6.1$ & $21.4 \pm 4.8$ \\
\hline $\begin{array}{l}\text { Duration of sym } \\
\text { ptoms (weeks) }\end{array}$ & & & & \\
\hline$($ mean $\pm S D)$ & $3.9 \pm 2.7$ & $4.0 \pm 2.6$ & $4.1 \pm 2.8$ & $4.0 \pm 2.7$ \\
\hline $\begin{array}{l}\text { Insulin dose } \\
\left(\mathrm{IU} \cdot \mathrm{kg}^{-1} \cdot \mathrm{day}^{-1}\right)\end{array}$ & & & & \\
\hline $\begin{array}{l}\text { (mean } \pm \mathrm{SD}) \\
\text { HLA-type }\end{array}$ & $0.53 \pm 0.27$ & $0.48 \pm 0.22$ & $0.55 \pm 0.32$ & $0.46 \pm 0.21$ \\
\hline DR 3,x n (\%) & $18(19)$ & $25(26)$ & $7(15)$ & $8(17)$ \\
\hline DR 4, $\mathrm{x} \cap(\%)$ & $36(39)$ & $43(45)$ & $22(48)$ & $24(52)$ \\
\hline DR $3,4 \mathrm{n}(\%)$ & $29(31)$ & $17(18)$ & $13(28)$ & $9(20)$ \\
\hline $\mathrm{DR} \times, \times \mathrm{n}(\%)$ & $10(11)$ & $10(11)$ & $4(9)$ & $5(11)$ \\
\hline $\begin{array}{l}\mathrm{HbA}_{1 c}(\%) \\
(\text { mean } \pm \mathrm{SD})\end{array}$ & $10.8 \pm 2.1$ & $10.4 \pm 2.6$ & $10.2 \pm 2.0$ & $10.0 \pm 2.8$ \\
\hline $\begin{array}{l}\text { C-peptide } \\
\text { (nmol/l) basal } \\
\text { (mean } \pm \text { SD) } \\
\text { stimulated }\end{array}$ & $0.20 \pm 0.09$ & $0.23 \pm 0.11$ & $0.21 \pm 0.07$ & $0.20 \pm 0.09$ \\
\hline$($ mean $\pm S D)$ & $0.33 \pm 0.21$ & $0.40 \pm 0.21$ & $0.35 \pm 0.15$ & $0.35 \pm 0.14$ \\
\hline
\end{tabular}

mer CsA patients in a single centre of the French CsA multicentre trial [11]. In that study the better Beta-cell function in the CsA group (but not the lower insulin dose) seems to have been preserved for at least 2 years after drug discontinuation. However, these data come from a small cohort and no attempt was made to select statistical twins. An earlier open study had indicated a rapid increase in insulin requirements after drug CsA discontinuation [4].

After 12 months of CsA treatment dose-dependent side-effects were observed as has been reported previously [3]. Follow-up showed normalization of all abnormal parameters within 6 months of discontinuation. The four major parameters are documented in this report. However, previous kidney biopsies had shown structural damage (moderate arteriolopathy, tubular atrophy or interstitial fibrosis) in specimens from some CsA patients [3]. Kidney function studies in the Danish cohort of the study indicated incomplete normalisation in three out of nine patients [12]. Subsequent trials with lower CsA doses than used in this study did not show renal injury in diabetic patients [13-15].

In conclusion, the data presented suggest that $\mathrm{CsA}$ administration transiently delayed the progression of Type 1 diabetes by its protective action on Beta-cell function. However, this effect was rapidly lost after discontinuation of cyclosporin $\mathrm{A}$. We conclude that the drug did not correct the immunoregulatory imbalance between Beta-cell destroying and protective activities in Type 1 diabetes. 

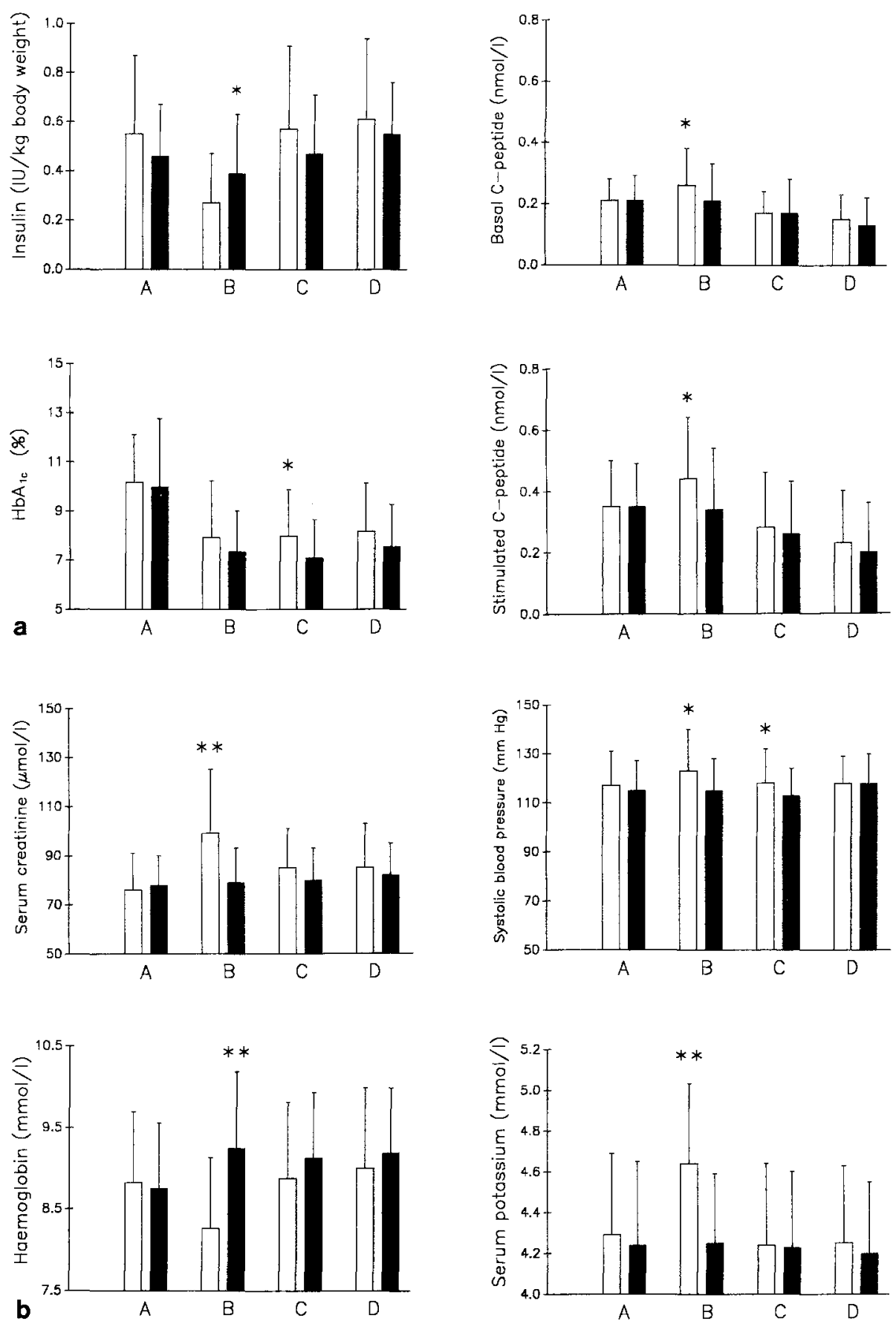

Fig. 2a,b. Effects and side-effects before and after discontinuation of study drug in 46 representative statistical twins with complete record. a Follow-up of metabolic parameters. b Follow-up of systolic blood pressure, serum creatinine, potassium and haemoglobin. Open columns, cyclosporin A(CsA) group; closed columns, placebo group; A, before start of therapy; $\mathrm{B}, 1-3$ months before discontinuation of $\mathrm{CsA} ; \mathrm{C}, 6$ months after CsA discontinuation; $D, 15$ months after CsA discontinuation. Bars indicate SD;

$*, p<0.05 ; * *, p<0.01$
Acknowledgements. We thank patients and their physicians for collaborating in the follow-up study. Complete listing of the CanadianEuropean Randomized Control Trial Group

Management committee: C.R.Stiller, H.Kolb, B.von Graffenried, M. Gent, J. Dupré, J. Nerup and G. Murphy.

Data centre: Robarts Research Institute, London, Ontario, Canada. M. Gent, A. Donner and N. Sommerville.

Participating staff: Canadian centres. Calgary, Alberta. Diabetes: R. G. McArthur and L. Day. Immunotherapy: J. Klassen. Co-ordinator: M. Campbell.

Halifax, Nova Scotia. Diabetes: M.H.Tan, S.Salisbury and A.H.Shlossberg. Immunotherapy: A.S. MacDonald. Co-ordinator: J.Salmond.

London, Ontario. Diabetes: J.Dupré, M.Jenner, N.W. Rodger and
J.Mahon. Immunotherapy: C. R.Stiller, P.A. Keown and D. Heinrichs. Co-ordinators: J. McDonald, S. Hayman and H. Sim.

Technologists: N. Tchelebi and C. Walter.

Montreal, Quebec. Diabetes: P. Hamet and J.L. Chiasson.

Immunotherapy: P. Robitaille. Co-ordinators: D. Bedard and L. Lortie.

Saskatoon, Saskatchewan. Diabetes: S. Van Vliet. Immunotherapy: R. Dyck. Co-ordinator: S. Rogers.

Vancouver, British Columbia. Diabetes: K. Dawson and W.J.Tze. Immunotherapy: C.E. Reeve. Co-ordinators: H.Nichol, S.Barrios and D. Mallory.

Winnipeg, Manitoba. Diabetes: A. Mehta. Immunotherapy: J. Jeffrey and D. Rush. Co-ordinator: S. Beghin.

European centres. Gentofte, Denmark. Diabetes: J.Nerup and T. Mandrup-Poulsen. Immunotherapy: K.Bendtzen, V.Andersen, E. Kemp and H.Dieperink. Co-ordinators: H.Espersen, 1. Torp, 

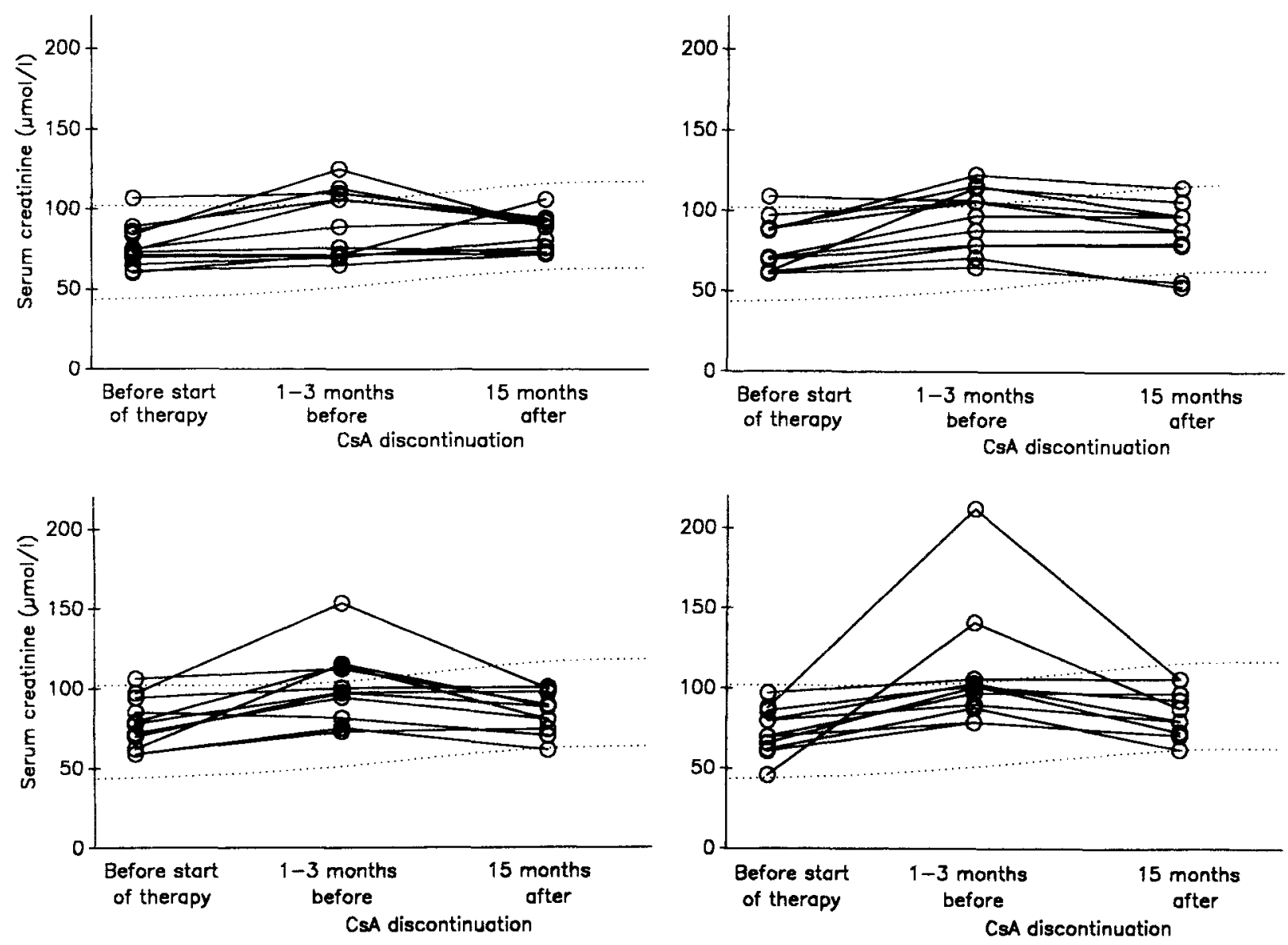

Fig.3. Follow-up of serum creatinine levels in 46 statistical twins of the cyclosporin A (CsA) group divided in four panels for easier

reading. Dotted lines indicate the normal range for the 46 twins of the placebo group

V.Nerup and H.Nissen. Technologists: M.Munck, U.Soegaard, J.Falk, S. Kjellberg and E. Schjerning.

Helsinki, Finland. Diabetes: V.A. Koivisto and R.Pelkonen. Immunotherapy: M. Leirisalo-Repo and U. Turunen. Co-ordinators: A. Lehtonen and A. Ojalammi.

Düsseldorf, FRG. Diabetes: F. A. Gries, B. Greulich and B. Pawlowski. Immunotherapy: B. Grabensee, K. Sprenger and A. Westhoff. Co-ordinator: J. Janitz.

Munich, FRG. Diabetes: E.Standl, T.Lander and H. Mehnert. Immunotherapy: C. Nerl, A.Ziegler and H. Kolb.

Vienna, Austria. Diabetes: G.Schernthaner, D. Klosch-Kasparek and G.Aschauer-Treiber. Immunotherapy: C.C.Zielinski and C. Muller.

External review committee: J.H. Dirks, Chairman, Vancouver, British Columbia, Canada; A. L. Drash, Pittsburgh, Pennsylvania, USA; C.H.Hollenburg, Toronto, Ontario, Canada; D. A.Pyke, London, UK; B. Weber, Berlin, FRG; F.S.Rolleston, Secretary, Ottawa, Ontario, Canada.

\section{References}

1. Stiller CR, Dupré J, Gent M, Jenner MR, Keown PA, Laupacis A, Martell R, Rodger NW, von Graffenried B, Wolfe BMJ (1984) Effects of cyclosporine immunosuppression in insulindependent diabetes mellitus of recent onset. Science 223: 13621367

2. Feutren G, Papoz L, Assan R, Vialettes B, Karsenty G, Vexiau P, Du Rostu H, Rodier M, Sirmai J, Lallemand A, Bach JF (1986)

Cyclosporin increases the rate and length of remissions in insulin-dependent diabetes of recent onset. Lancet II: 119-123

3. The Canadian/European Randomized Control Trial Group (1988) Cyclosporin-induced remission of IDDM after early intervention. Association of 1 yr of cyclosporin treatment with enhanced insulin secretion. Diabetes 37:1574-1582

4. Dupré J, Stiller CR, Gent M, Donner A, von Graffenried B, Murphy G, Heinrichs D, Jenner MR, Keown PA, Laupacis A, Mahon J, Martell R, Rodger NW, Wolfe BW (1988) Effects of immunosuppression with cyclosporine in insulin-dependent diabetes mellitus of recent onset: The Canadian open study at 44 months. TranspI Proc XX [Suppl 4]: 184-192

5. Assan R, Feutren G, Sirmai J (1988) Cyclosporine trials in diabetes: updated results of the French experience. Transpl Proc XX [Suppl 4]: 178-183

6. Dupré J. Stiller CR, Gent M, Donner A, von Graffenried B, Heinrichs D, Jenner M, Keown P, Mahon J, Martell R, Momah CI, Murphy G, Rodger NW, Wolfe BM (1988) Clinical trials of cyclosporin in IDDM. Diabetes Care 11 [Suppl 1]: 37-44

7. Andreani D, Kolb H, Pozzilli P (1989) Immunotherapy of type 1 diabetes. John Wiley \& Sons, Chichester

8. Like AA, Dirodi V, Thomas S, Guberski DL, Rossini AA (1984) Prevention of diabetes mellitus in the $\mathrm{BB} / \mathrm{W}$ rat with cyclosporin-A. Am J Pathol 117: 92-97

9. Brayman KL, Armstrong J, Barker CF, Naji A (1986) Intermittent cyclosporine administration and prevention of diabetes in the BB rat. Transpl Proc XVIII: $1545-1547$

10. Jaworski MA, Jewell LD, Honore L, Metha JG, Bayens-Simmonds J, McGuire-Clark P, Schouls JJ, Yap WY (1987) Immunosuppression in autoimmune disease: the double-edged sword in BB rat. Clin Invest Med 10: 488-495 
11. Vague P, Vialettes B, Picq R, Dol S, Lassmann-Vague V (1989) Effect of cyclosporin A on B-cell loss in Type 1 (insulin-dependent) diabetes mellitus. Diabetologia 32: 887-888 (Letter)

12. Feldt-Rasmussen B, Jensen T, Dieperink H, Mandrup-Poulsen T, Nerup J, Bendtzen K, Andersen V, Kemp E, Leyssac PP (1990) Nephrotoxicity of cyclosporin A in patients with newly diagnosed type 1 diabetes mellitus. Diab Med 7: 429-433

13. Bougneres PF, Carel JC, Castano L, Boitard C, Gardin JP, Landais P, Hors J, Mihatsch MJ, Paillard M, Chaussain JL, Bach JF (1988) Factors associated with early remission of type 1 diabetes in children treated with cyclosporine. N Engl J Med 318: 663-670

14. Feutren $G$ (1988) Functional consequences and risk factors of chronic cyclosporine nephrotoxicity in type 1 diabetes trials. Transpl Proc XX [Suppl 4]: 356-366

15. Bougneres PF, Landais P, Boisson C, Carel JC, Frament N, Boitard C, Chaussain JL, Bach JF (1990) Limited duration of remission of insulin dependency in children with recent overt type I diabetes treated with low-dose cyclosporin. Diabetes 39 : 1264

Received: 27 November 1990

and in final revised form: 4 March 1991

Prof. H. Kolb

Diabetes Research Institute

Auf'm Hennekamp 65

W-4000 Düsseldorf

FRG

Prof. Dr. C. Stiller

University Hospital

P.O. Box 5339

London, Ontario N6A 5 A5

Canada 